\title{
PENGGUNAAN ALAT KOMPRESOR PADA MOTOR BAKAR TORAK SEBAGAI FUNGSI TAMBAHAN KENDARAAN RODA DUA
}

\author{
Dwi Irawan \\ Jurusan Teknik Mesin Fakultas Teknik Universitas Muhammadiyah Metro \\ J1. KH. Dewantara No. 116 Metro Telp. (0725)45932-42445 Kode pos 34111 \\ HP : 081379891101, E-mail : Dwi_irawan12@yahoo.co.id
}

\begin{abstract}
ABSTRAK
Melihat keadaan sekitar kita masih banyak tempat-tempat atau jalan-jalan yang masih jauh dari keramaian atau permukiman penduduk. Sehingga apabila kita berpergian menggunakan sepeda motor kita butuh alat cadangan kompresor bila ban sepeda motor kita kempes dijalan ditempat yang jauh dari keramaian. Alat cadangan yang dirancang yaitu kompresor udara, yang sumber tenaganya memanfaatkan tekanan kompresi dari ruang bakar pada kendaraan motor roda dua. Bahan-bahan yang dipakai bisa dengan memanfaatkan dari komponen bekas (limbah), seperti busi, katup tekanan balik, selang, nozel kompresor dan klem selang.

Alat ini dirancang dengan tujuan sebagai alat alternatif pada kondisi darurat, yang untuk kerja tergantung pada: tekanan udara, volume, efisiensi dan daya adiabatik. Sedangkan factor yang paling dominan adalah prestasi kerja torak dan silinder sebagai penghasil tekanan yang natabennya merupakan tekanan kompresi pada ruang bakar, untuk mengetahui kemampuan kompresor maka dilakukan beberapa perlakuan pengujian yang meliputi tekanan udara masuk, tekanan udara keluar dan volume silinder, dan temperatur yang saling mempengaruhi, apabila tekanan turun maka temperaturnya juga turun, apabila volumenya meningkat maka tekanannya akan menurun. Sedangkan proses yang berlaku adalah cara kompresi adiabatik yang menghasilkan tekanan $1205 \mathrm{kPa}$.

Dari hasil pengujian dan perhitungan didapat tekanan sebesar $13,6 \mathrm{~cm}^{3}$, dan kapasitasnya $0,0118 \mathrm{~m}^{3} / \mathrm{menit}$. Untuk mengurangi resiko akibat penggunaan alat kompresor ini maka silinder yang digunakan adalah silinder sepeda motor 4 tak, karena motor bakar 4 tak menggunakan sistem pelumasan yang berstandar sirkulasi minyak pelumas. Jadi alat kompresor ini tidak menimbulkan kerusakan atau keausan tingkat berat pada komponenkomponen pembangkit daya motor bakar.
\end{abstract}

Kata kunci : Kompresor, 4 tak, tekanan kompresi, volume, efisiensi.

\section{PENDAHULUAN}

Negara Indonesia negara yang sangat luas dan terdiri dari beribu-ribu pulau dan dengan penyebaran penduduk yang tidak merata serta masih banyak daerahdaerah yang terpencil yang belum dihuni oleh masyarakat luas. Melihat keadaan yang ada di sekitar kita hingga saat ini masih banyak tempat-tempat atau jalan-jalan yang masih, dan jauh dari keramaian atau pemukiman penduduk.

Untuk menjangkau daerah yang jauh harus menggunakan alat transportasi, dan salah satu alat trnsportasi yang mudah untuk digunakan adalah sepeda motor. Mengingat daerah kita yang masih sepi, sehingga apabila kita bepergian melalui tempat-tempat yang jauh dari keramaian atau pemukiman penduduk yang jarang, dan saat itu terjadi kerusakan seperti ban motor kempes yang mengakibatkan kesulitan untuk melanjutkan perjalanan. Secara tidak langsung kita membutuhkan bengkel untuk memperbaiki.
Dikarenakan kondisi yang digambarkan diatas sulit untuk mencari bengkel, sehingga kita butuh sebuah alat yang praktis, simple, dan pastinya besar manfaatnya, serta tidak menyulitkan kita untuk membawa dan mempergunakan alat tersebut.

Alat yang di rancang yaitu kompresor udara yang sumber tenaganya memanfaatkan tekanan kompresi dari ruang bakar pada kendaraan bermotor roda dua. Penggunaan alat ini di lakukan pada saat mesin tidak hidup (mati), serta busi dibuka dan dilepas kemudian dipasang alat tersebut. Kemudian motor atau kendaraan diengkol, dan proses kompresi udara di ruang bakar akan mengisi udara dengan tekanan sehingga ban sepeda motor akan penuh.

Alat tersebut terdiri dari selang, pipa, katup, ulir busi, dan nosel. Alat ini selain simpel bentuknya penggunaannya juga sangat mudah. Kita bisa meletakan alat ini dibawah sadel atau jok sepeda motor kita, jadi kita tidak kerepotan untuk menyimpan atau meletkan alat kompresor udara ini. 
Tujuan Penelitian ini adalah

1. Untuk mengetahui berapa tekanan udara yang dihasilkan.

2. Mengetahui berapa beda tekanan kompresi pada ruang bakar.

3. Mengetahui efisiensi alat tersebut.

Manfaat penelian adalah

1. Mendapatkan alat yang simple dan praktis yang mudah dibawa.

2. Membantu masyarakat apabila mengalami kerusakan ban didaerah yang terpencil.

3. Mendapatkan fungsi ganda dari ruang bakar yaitu sebagai kompresor udara

\section{LANDASAN TEORI}

\subsection{Kompresor}

Kompresor adalah mesin untuk memampatkan udara atau gas. Kompresor udara biasanya mengisap udara dari atmosfir. Dalam hal ini kompresor bekerja sebagai penguat (boster). Sebaliknya ada pula kompresor yang mengisap gas yang bertekanan lebih rendah dari pada tekanan atmosfir. Dalam hal ini kompresor disebut pompa vakum. Banyak alat dan cara untuk mengolah udara misalnya kompresor dengan tenaga manusia atau yang digerakan dengan mesin/motor. Udara mempunyai manfaat sangat luas sehingga banyak dibuat peralatan untuk menghasilkan udara bertekanan, seperti pengisian udara pada ban kendaraan dan alat kerja yang memanfaatkan tenaga pneumatik. Oleh karena itu udara dikelola agar dapat dikumpulkan atau ditampung, dipadatkan dan disimpan, bahkan untuk kebutuhan tertentu dilengkapi komponen pendukung lain, dari cara yang sederhana hingga teknologi khusus.

Azas Kompresor Jika suatu gas didalam sebuah ruangan tertutup diperkecil volumenya, maka gas akan mengalami kompresi. Kompresor yang menggunakan azas jenis ini disebut kompresor jenis perpindahan (displacement). Di sini digunakan torak yang bergerak bolak-balik di dalam sebuah slinder untuk mengisap, menekan, dan mengeluarkan gas secara berulang-ulang. Dalam hal ini gas yang ditekan tidak boleh bocor melalui celah antara dinding torak dan dinding silinder yang bergesek. Untuk itu digunakan cincin torak sebagai perapat.

Untuk mendukung proses pemindahan tersebut dibutuhkan beberapa komponen yang terangkai dalam suatu system yang bekerja dengan memanfaatkan sumber pengerak dari luar. Kompresor adalah tergolong dalam mesin kerja yang terdiri dari system mekanis, proses kompresi gas, kemudian dari masing-masing system dan proses akan dapat bekerja secara normal apabila terpenuhi tahapan pemampatan udara.

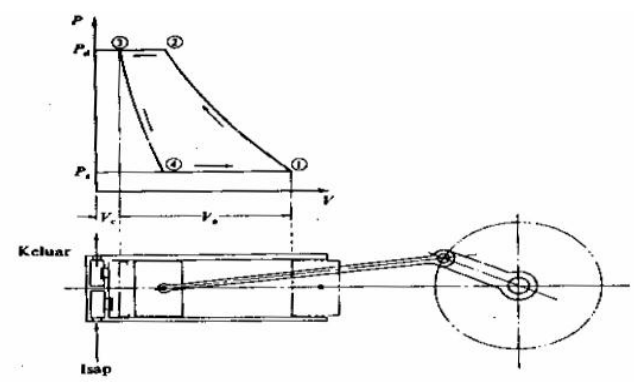

Gambar 1. Diagram P-V dari kompresor

Sumber : (Usman \& sardjijo :1979)

\subsection{Proses Kompresi Gas}

Kompresi gas dapat dilakukan menurut tiga cara yaitu dengan proses isothermal, adiabatic, dan politropik. Adapun perilaku masing-masing proses ini dapat diuraikan sebagai berikut.

1. Kompresi Isothermal

Bila suatu gas dikompresikan, maka ini berarti ada energi mekanik yang berikan dari luar kepada gas. Energi ini diubah menjadi energi panas sehingga temperature gas akan naik jika tekanan semakin tinggi. Namun, jika proses kompresi ini dibarengi dengan pendinginan untuk mengeluarkan panas yang terjadi, temperature dapat dijaga tetap

\section{Kompresi Adiabatik}

Jika silinder diisolasi secara sempurna terhadap panas, maka kompresi akan berlangsung tanpa ada panas yang keluar dari gas atau masuk kedalam gas. Proses semacam ini disebut proses adiabatik. Dalam proses ini tidak pernah terjadi secara sempurna karena isolasi dalam silinder tidak pernah dapat sempurna. Namun proses ini sering dipakai dalam pengkajian teoritis proses kompresi.

3. Kompresi Politropik

Kompresi pada kompresor yag sesungguhnya bukan merupakan proses Isothermal, karena ada kenaikan temperatur, namun juga bukan proses adiabatic karena ada panas yang dipancarkan keluar. Jadi kompresi yang sesungguhnya, ada diantara keduanya dan disebut kompresi politropik

\subsection{Hubungan antara tekanan dan volume}

Jika sebuah alat penyuntik tanpa jarum dan berisi udara atau gas, kemudian tutup ujungnya dengan jari telunjuk dan tangkainnya didorong dengan ibu jari, maka pada jari telunjuk akan terasa adannya tekanan yang bertambah besar. Bertambahnya tekanan tersebut adalah merupakan akibat dari mengecilnya volume udara di dalam silinder karena dimampatkan oleh torak. Jika volume semakin dikecilkan tekanan akan semakin besar. Hubungan antara tekanan dan volume gas dalam proses kompresi tersebut dapat diuraikan sebagai berikut. Jika selama kompresi, temperature gas dijaga tetap (tidak bertambah panas) maka pengecilan volume 
menjadi 1/2 kali akan menaikan tekanan menjadi 2 kali lipat.

Demikian pula jika volume menjadi $1 / 3$ kali,tekanan akan menjadi 3 kali lipat. Jadi secara umum dapat dikatakan sebagai berikut "jika gas dikompresikan (atau diekspansikan) pada temperature tetap, maka tekanannya akan berbanding terbalik dengan volumenya". Pernyataan ini disebut hukum boyle dan dapat dirumuskan pula sebagai berikut : jika suatu gas mempunyai volume $\mathrm{V}_{1}$ dan tekanan $\mathrm{P}_{1}$ dimampatkan pada temperature tetap hingga volumenya menjadi $\mathrm{V}_{2}$ dimana volume dapat dihitung dengan rumus sebagai berikut.

$$
C=\frac{V_{L} \cdot V_{2}}{V_{2}}
$$

(Sularso : 1983)

Dimana :

$\mathrm{C}=$ Perbandingan kompresi

$\mathrm{V}_{2}=\operatorname{Volume}\left(\mathrm{cm}^{3}\right)$

$\mathrm{V}_{\mathrm{L}}=$ Volume langkah $\left(\mathrm{cm}^{3}\right)$

Setelah $\mathrm{V}_{2}$ diketahui kita bisa mencari $\mathrm{P}_{2}$ dengan menggunakan rumus sebagai berikut:

$$
\mathrm{P}_{1} \mathrm{~V}_{1}=\mathrm{P}_{1} \mathrm{~V}_{2}=\text { tetap } \quad \text { (Sularso : 1983) }
$$

Dimana :

$\mathrm{P}_{1}=$ Tekanan awal $(\mathrm{Pa})$

$\mathrm{P}_{2}=$ Tekanan akhir $(\mathrm{Pa})$

$\mathrm{V}_{1}=$ Volume awal $\left(\mathrm{cm}^{3}\right)$

$\mathrm{V}_{2}=$ Volume akhir $\left(\mathrm{cm}^{3}\right)$

\begin{tabular}{|c|c|c|c|}
\hline Volume Thenen & $\begin{array}{c}\text { Komplpasti } \\
\text { irolemilk }\end{array}$ & $\begin{array}{l}n=1,25 \\
\text { kompers } \\
\text { policiopit }\end{array}$ & $\begin{array}{l}\text { Kompreai } \\
\text { sdiobail }\end{array}$ \\
\hline 1 & I & I & 1 \\
\hline$i / 2$ & 2 & 2,38 & 2,64 \\
\hline $1 / 3$ & 3 & 3,95 & 4,56 \\
\hline $1 / 4$ & 4 & $5 ; \%$ & 6,91 \\
\hline $1 / 5$ & 5 & 7,5 & 9,09 \\
\hline $1 / 6$ & 6 & 9,4 & 12,3 \\
\hline$n$ & 7 & 11,4 & 15,1 \\
\hline $1 / 8$ & 8 & 13,5 & 18,4 \\
\hline 18 & 9 & 13,6 & 21,7 \\
\hline $1 / 10^{\circ}$ & 10 & 17,8 & 25,1 \\
\hline $1 / 4$ & $1 i$ & 30,0 & 28,3 \\
\hline
\end{tabular}

Tabel 1 Hubungan Hubungan volume dan tekanan

Sumber : (Sularso : 1983)

\subsection{Hubungan Antara Temperatur dan Volume}

Dari pengukuran koefisien muai berbagai gas diperoleh kesimpulan : "semua macam gas apa bila dinaikkan temperaturnya sebesar $1^{0} \mathrm{C}$ pada tekanan tetap, akan mengalami pertambahan volume sebesar 1.273 dari volumenya $0^{0} \mathrm{C}$ sebaliknya apabila diturunkan temperaturnya sebesar $1{ }^{0} \mathrm{C}$, akan mengalami pengurangan volume dengan proporsi yang sama”.(hukum charles) .

$\frac{V_{2}}{V_{2}}=\frac{\left(273+t_{1}\right)}{\left(273+t_{2}\right)}$

(Sularso : 1983)

Dimana :

$V_{1}=$ Volume awal $\left(\mathrm{m}^{3}\right)$

$V_{2}=$ Volume akhir $\left(\mathrm{m}^{3}\right)$

$t_{1}=$ Temperatur awal $\left({ }^{0} \mathrm{C}\right)$

$t_{2}=$ Temperature akhir $\left({ }^{0} \mathrm{C}\right)$

\subsection{Sifat-sifat Udara}

\section{a. Berat Jenis Udara}

Berat jenis gas (termasuk udara) dapat bervariasi tergantung pada tekanan dan temperaturnya. Karena itu untuk menyatakan berat jenis suatu gas harus disebutkan pula tekanan dan temperaturnya. Dalam praktek ada dua macam kondisi patokan seperti di bawah ini:

1. Kondisi Standar Industri

Udara dengan kondisi ini mempunyai keadaan sebagai berikut:

Temperature : 200C (2930K)

Tekanan mutlak : 0,1013 Mpa

Kelembapan relative : $65 \%$

Berat jenis : 11,807 N/m3

2. Kondisi Normal Teoritis

Udara dengan kondisi ini mempunyai keadaan sebagai berikut:

Temperatur : 0O C (2730K)

Tekanan mutlak : 0,1013 Mpa

Berat jenis : $12,68 \mathrm{~N} / \mathrm{m} 3$

\subsection{Panas Jenis Udara}

1. Panas Jenis Pada Tekanan Tetap

Jika silinder dipanaskan maka gas akan mengembang mendorong torak keatas sehingga tekanan didalam silinder tidak berubah. Dalam hal demikian jumlah panas yang diperlukan untuk menaikan temperatur $1 \mathrm{~kg}$ gas tersebut sebesar $1^{0} \mathrm{C}$ disebut panas jenis pada tekanan tetap. Pada jenis ini biasannya diberi lambang $\mathrm{c}_{\mathrm{p}}$, dimana untuk udara $\mathrm{c}_{\mathrm{p}}=0,24 \mathrm{kcal} /\left(\mathrm{kg}^{0} \mathrm{C}\right)=1,005$ $\mathrm{kJ} /\left(\mathrm{kg}^{0} \mathrm{C}\right)$.

2. Panas Jenis Pada Volume Tetap

Jika $1 \mathrm{~kg}$ gas ditempatkan dalam sebuah bejana lalu dipanaskan tanpa dapat berkembang maka tekanan dan temperaturnya akan naik. Jumlah panas yang diperlukan untuk menaikan temperature $1 \mathrm{~kg}$ gas ini sebesar $1^{0} \mathrm{C}$ dalam keadaan demikian disebut panas jenis pada volume tetap. Panas jenis ini biasanya diberi lambang $\mathrm{c}_{\mathrm{v}}$, dimana untuk udara $\mathrm{c}_{\mathrm{v}}=0,17 \mathrm{kcal} /\left(\mathrm{kg}^{0} \mathrm{C}\right)=0,712$ $\mathrm{kJ} /\left(\mathrm{kg}^{0} \mathrm{C}\right)$. 


\subsection{Perubahan Temperatur}

Pada waktu kompresi, temperature gas dapat berubah tergantung pada jenis proses yang dialami. Untuk masing-masig proses, hubungan antara temperature dan tekanan adalah sebagai berikut :

\section{Proses Isothermal}

Di dalam proses ishothermal ini tempertur dijaga tetap sehingga tidak berubah.

\section{Proses Adiabatik}

Dalam proses adiabatik tidak ada panas yang dibuang keluar silinder atau dimasukkan, sehingga seluruh kerja mekanis yang diberikan dalam proses ini akan dipakai menaikan temperature gas. Temperatur yang dicapai oleh gas yang keluar dari kompresor dalam proses adiabatik dapat diperoleh secara teoritis dengan rumus:

$$
t_{2}=t_{1}\left(P_{2} / P_{1}\right)^{k-1 / m k)}
$$

(Sularso : 1983)

Dimana :

$\mathrm{t}_{1}=$ Temperatur mutlak gas keluar kompresor $(\mathrm{K})$

$\mathrm{t}_{1}=$ Temperatur isap gas masuk kompresor $(\mathrm{K})$

$\mathrm{p}_{1}=$ Tekanan awal $(\mathrm{Pa})$

$\mathrm{p}_{2}=$ Tekanan akhir $(\mathrm{Pa})$

$\mathrm{m}=$ Jumlah tingkat kompresi.

$\mathrm{k}=$ Konstanta udara $\left(\mathrm{c}_{\mathrm{p}} / \mathrm{c}_{\mathrm{v}}\right)$

\section{Proses Politropik}

Jika selama kompresi udara didinginkan, misalnya dengan memakai air pendingin untuk silinder, maka sebagian panas yang timbul akan dikeluarkan. Temperatur pada kompresor yang sesungguhnya, tergantung pada ukuran dan jenisnya, dan biasanya diusahakan serendah-rendahnya.

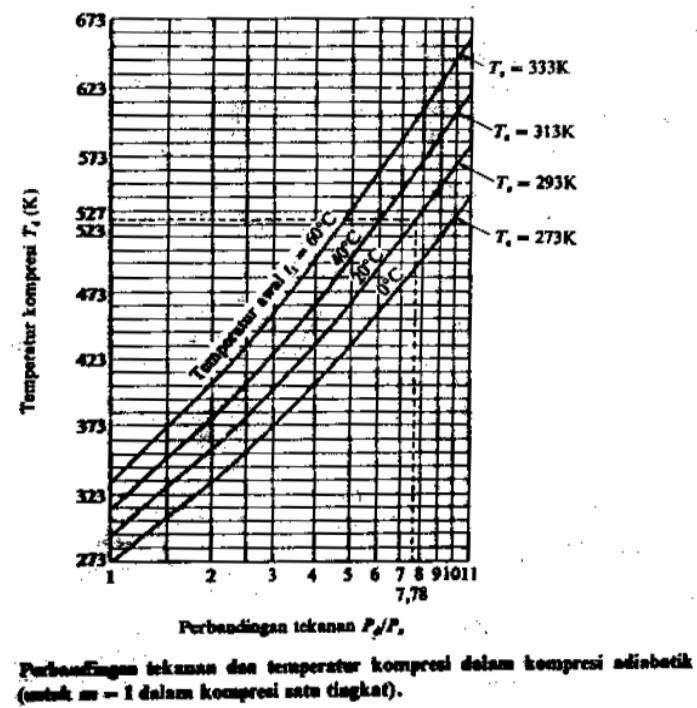

Gambar 2 Perbandingan Tekanan

Sumber : (Sularso: 1983)

\subsection{Efisiensi volumetrik}

Efisiensi volumetrik tergantung pada faktor-faktor rancangan kompresor seperti bentuk dan ukuran silinder, dan susunan katup. Besarnya efisien volumetrik dapat dihitung secara teoritis berdasarkan volume udara yang dapat diisap secara efektif oleh piston pada langkah isapnya. Adapun efisiensi volumetrik (vๆ) didefinisikan sebagai berikut :

$$
\eta_{v}=\left\{1-\varepsilon\left[\left\langle\frac{P_{2}}{P_{1}}\right\rangle^{1 / 2}-1\right]\right\} \quad(\text { Dietzel : 1988) }
$$

dimana :

$\varepsilon=\mathrm{V}_{1} / \mathrm{V}_{2}$ Volume sisa relatip

$\mathrm{p}_{1}=$ Tekanan awal $(\mathrm{Pa})$

$\mathrm{P}_{2}=$ Tekanan akhir $(\mathrm{Pa})$

$\mathrm{z}=$ Koefisien ekspansi

\subsection{Perpindahan Torak}

Perpindahan torak menyatakan kemampuan teoritis torak menghasilkan volume udara tiap menit. Namun dalam kompresor yang sesungguhnya volume udara yang dikeluarkan adalah lebih kecil dari pada perpindahan torak. Adapun rumus untuk mencari perpindahan torak adalah sebagai berikut :

$$
Q_{t h}=V_{s} . n
$$

(Sularso : 1983)

Dimana :

$Q_{t h}=$ perpindahan torak $(\mathrm{m} / \mathrm{mnt})$

$V_{s}=$ volume gas pemampatan $(\mathrm{m})$

$n=$ putaran poros engkol $(\mathrm{rpm})$

\subsection{Efisiensi Adibatik}

Efisiensi adiabatik didefinisikan sebagai daya yang diperlukan untuk memampatkan udara dengan siklus adiabatik (menurut perhitungan teoritis), dibagi dengan daya yang sesungguhnya diperlukan oleh kompresor. Untuk efisiensi adiabatik dihitung dengan menggunakan rumus :

$$
\eta_{\mathrm{ad}}=\frac{L_{a d}}{L_{S}}
$$

(Sularso : 1983)

dimana :

$\eta_{\text {ad }}=$ Efisiensi adiabatik

$L_{a d}=$ Daya adiabatik teoritis $(\mathrm{kW})$

$L_{s}=$ Daya yang masuk dalam kompresor $(\mathrm{kW})$

Sedangkan Besarnya daya adiabatik dapat dihitung dengan menggunakan rumus :

$$
L_{a d}=\frac{m k P_{1} \cdot Q_{S}}{k-1.60000}\left[\left\langle\frac{P_{2}}{P_{1}}\right\rangle^{(k-1) / m k}-1\right](\text { Sularso : 1983) }
$$



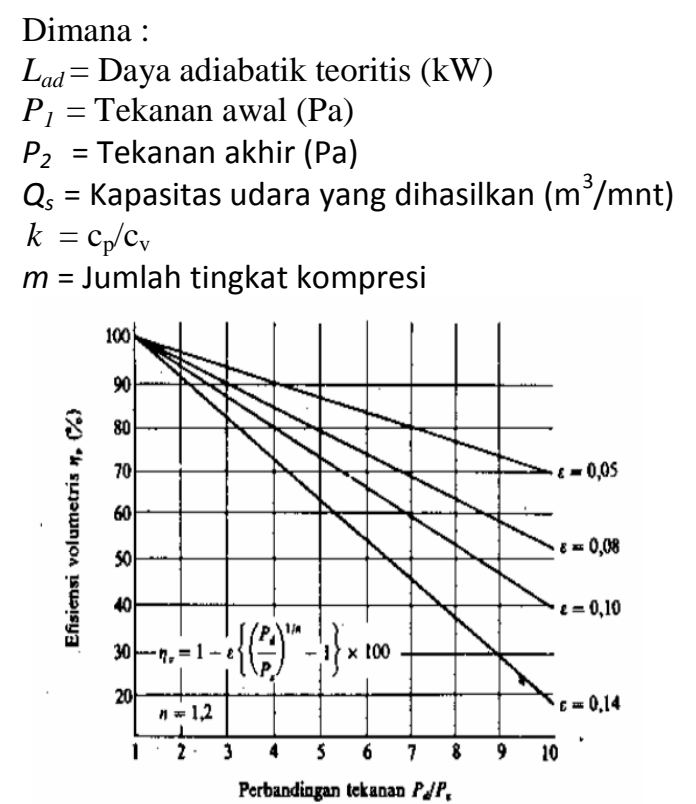

Gambar 3 Efisiensi Volumetrik dan perbandingan tekanan

Sumber : (Sularso: 1983)

\section{METODE}

Dalam penelitian ini menggunakan metode eksperimen (Research Method). Obyek penelitian adalah merancang alat kompresor pada motor bakar torak sebagai fungsi tambahan kendaraan roda dua.

\section{Alat dan Bahan}

Alat yang di gunakan :

1. 1 set mesin bor

2. Tang

3. Tanggem

4. Obeng

5. Kunci pas dan ring

6. Gegaji besi

7. Alat ukur kompresi

8. Alat ukur putaran

9. Kunci busi

10. Alat ukur kevakuman

Bahan yang di gunakan :

1. Busi bekas

2. Selang

3. Katub

4. Klem

5. Adaptor

\section{Pembuatan Alat}

Tahapan - tahapan dalam pembuatan alat pompa udara adalah sebagai berikut:

1. Mengebor busi
2. Memasang selang pada busi

3. Memasang katup antara selang

4. Memasang adaptor pada ujung selang

5. Mengklem setiap sambungan selang dengan bahan yang lain

\section{Proses Kerja Alat}

Dalam proses kerja alat kompresor udara menitik beratkan pada tekanan kompresi pada ruang bakar motor bakar torak, dari dari ruang bakar tersebut dilanjutkan melalui alat kompresor ini menuju ban sepeda motor yang akan kita isi udara. Untuk lebih jelasnya lihat pada diagram alur kerja alat kompresor udara sebagai berikut :

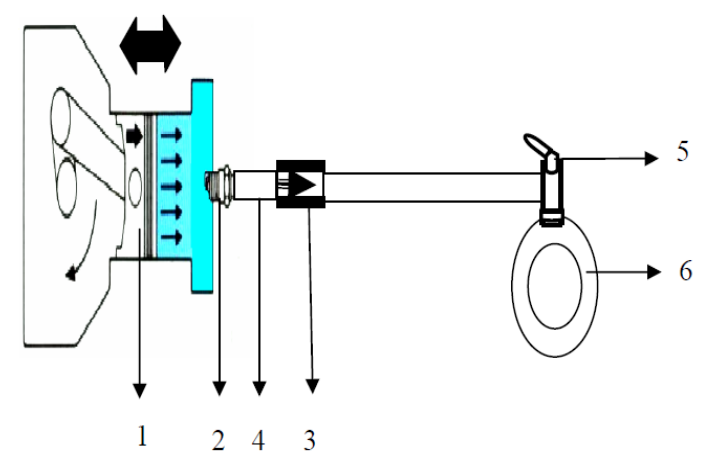

Gambar 4. Proses kerja alat kompresor

Keterangan :

1. Piston bekerja naik turun dari TMA menghisap udara lalu udara ditekan menuju TMB yang dilanjutkan ke busi.

2. Busi adalah alat yang bekerja meneruskan laju udara dari TMB menuju selang.

3. Selang adalah alat yang bekerja sebagai jalan untuk bergeraknya udara menuju adaptor tetapi melewati katup terlebih dahulu.

4. Katup bekerja membuat aliran udara menjadi searah, jadi udara yang sudah melewati katup tidak bisa terhisap lagi oleh piston.

5. Adaptor adalah alat untuk menyalurkan udara ke ban sepeda motor kita yang akan menekan pentil ban supaya udara dapat masuk ke ban dengan mudah.

6. Ban adalah alat yang akan di isi udara.

\section{Proses Pengujian}

Di dalam proses pengujian melalui langkahlangkah sebagai berikut:

1. Mengukur tekanan awal kompresi. Menggunakan vakum meter, dengan cara selang vakum meter dimasukan intek manipol, lalu diengkol atau di statr nanti disitu akan diketahui berapa tekanan besar awalnya. 
2. Mengukur tekanan akhir kompresi tanpa dipasang alat kompresor udara. Menggunakan kompresi tester, dengan cara kita tekan ujung alat kompresi tester kelubang busi yang sebelumnya busi sudah dilepas, lalu mesin kita engkol atau distater, dan pada saat itulah akan diketahui seberapa besar tekanan akhir kompresinya.

3. Mengukur tekanan akhir kompresi dengan dipasang alat kompresor udara. Menggunakan kompresor tester dengan cara kita masukan ujung alat kompresi tester kelubang nosel alat kompresor udara, setelah itu kita engkol mesin atau di start, nanti disitu akan muncul juga nilai tekanan akhir kompresinya.

4. Mengukur putaran (rpm) pada poros engkol. Menggunakan tacho meter dengan cara kabel positif pada tacho meter kita sambungkan pada CDI pengapian, dan kabel negatif sambung ke masa, setelah iku mesin diengkol atau distart, disitu akan diketahui seberapa besar putaran poros engkol yang dihasilkan.

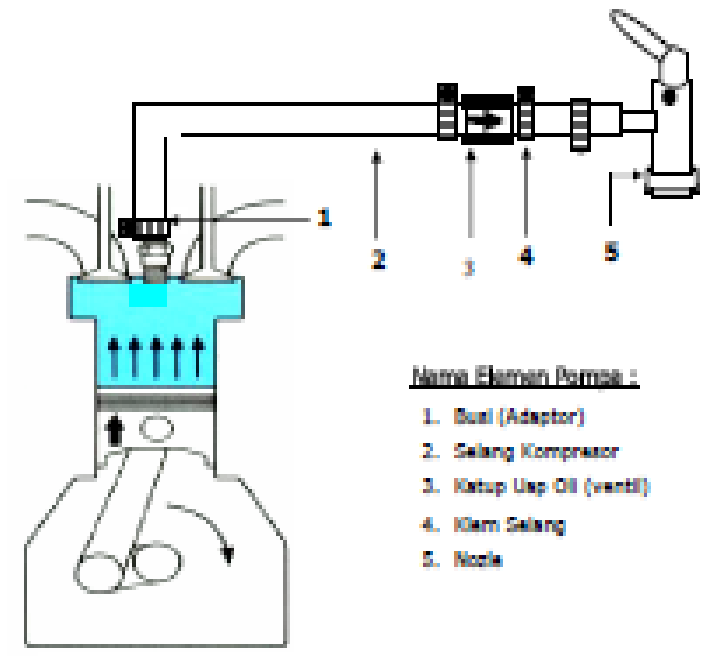

Gambar 5. Skema alat kompresor

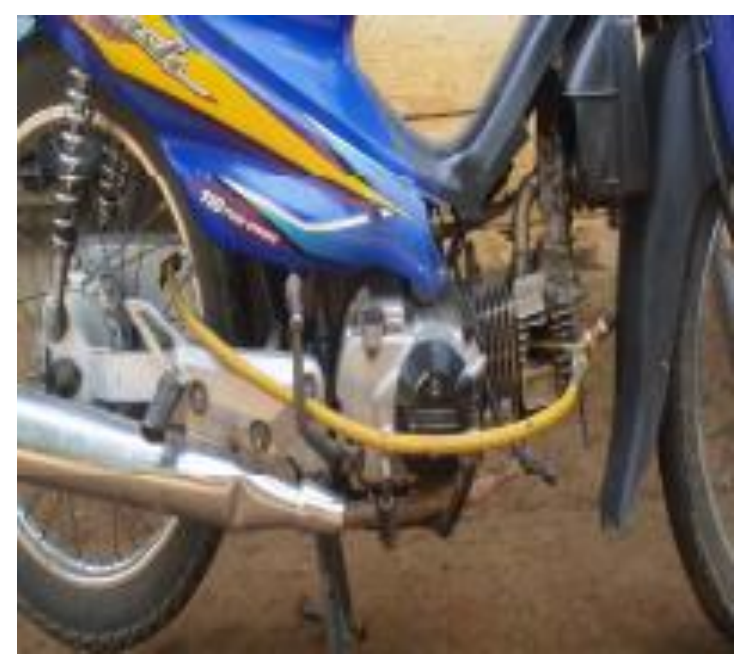

Gambar 6. Pemasangan alat kompresor

\section{Hasil dan Pembahasan}

Dari pengujian dan pengolahan data penggunaan alat kompresor sebagai fungsi tambahan motor roda dua dapat dilihat sebagai berikut:

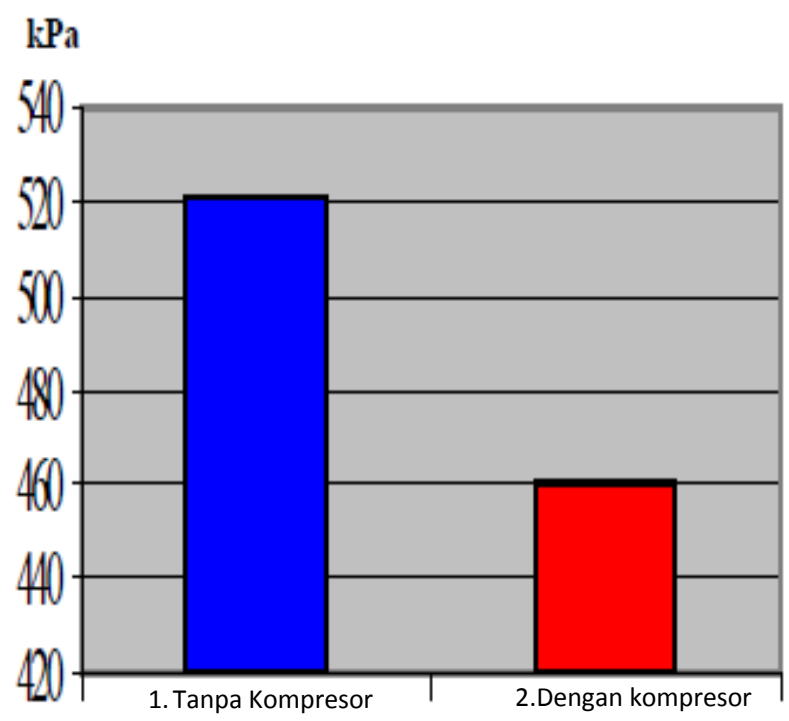

Gambar 7. Grafik perbedaan tekanan kompresi sebelum dan sesudah menggunakan alat kompresor

Dari gambar 7 terlihat bahwa Tekanan mengalami penurunan yang dikarenkan udara yang dulunya dimampatkan sekarang disalurkan ketempat lain melalui alat kompresor udara jadi volume akhir kompresi membesar.

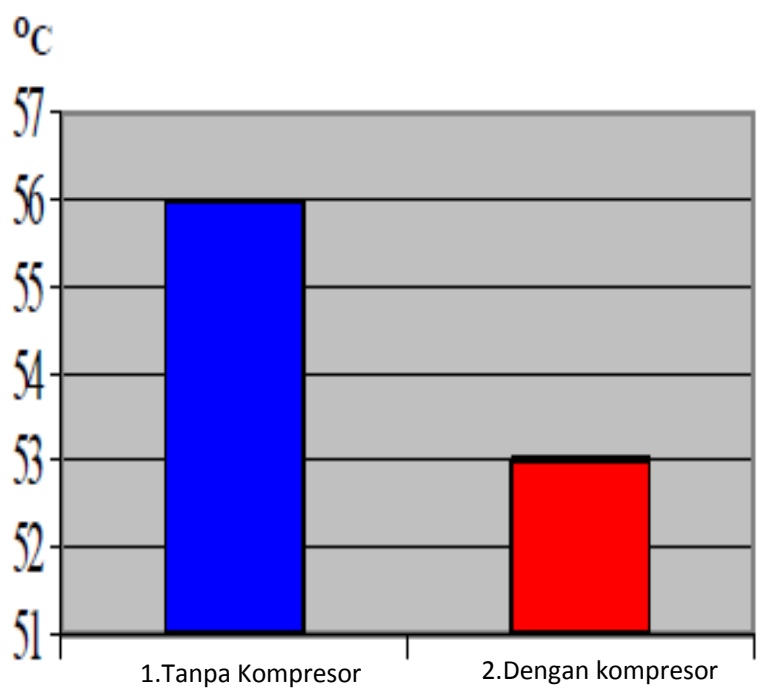

Gambar 8. Grafik temperatur sebelum dan sesudah menggunakan alat kompresor 
Dari gambar 8 terlihat temperatur setelah menggunakan alat kompresor dikarenakan tekanan udaran setelah menggunakan alat kompresor juga menurun.

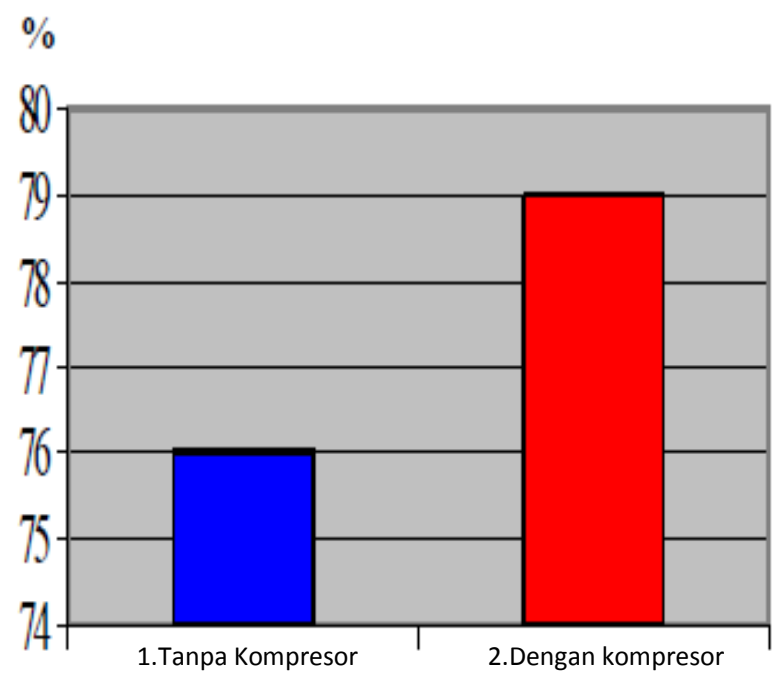

Gambar 9. Grafik efisiensi volumetrik sebelum dan sesudah menggunakan alat kompresor

Dari gambar 9 terlihat Efisiensi volumetrik naik dikarenakan volume akhir kompresi membesar mengakibatkan tekananya menurun.

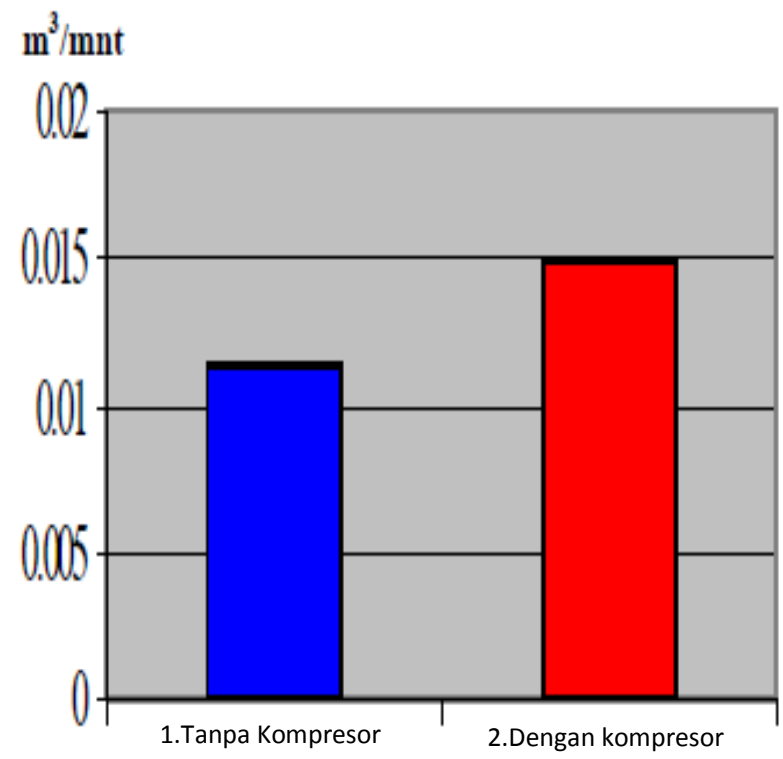

Gambar 10. Grafik kapasitas udara sebelum dan sesudah menggunakan alat kompresor

Dari gambar 10 terlihat kapasitas udara setelah menggunakan alat komresor naik ini dikarenakan evisiensi volumetriknya naik.

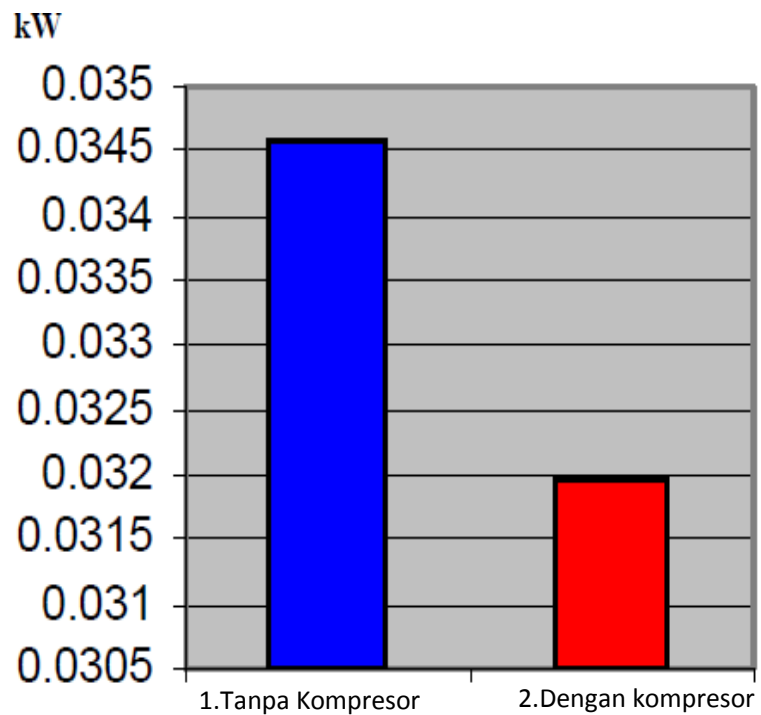

Gambar 11. Grafik Daya adiabatik sebelum dan sesudah menggunakan alat kompresor

Dari gambar 11 terlihat daya adiabatik menurun disebabkan tekanannya menurun.

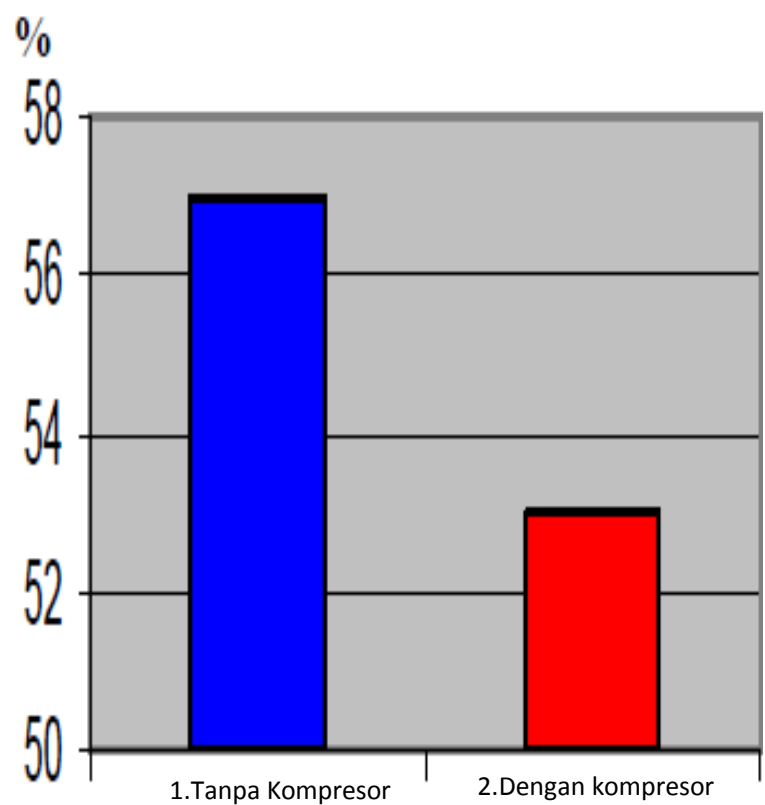

Gambar 12. Grafik efisiensi adiabatik sebelum dan sesudah menggunakan alat kompresor

Dari gambar 12 terlihat efisiensi adiabatik menurun disebabkan daya adiabaik setelah menggunakan alat komresor menurun. 


\section{Kesimpulan dan Saran}

\section{Kesimpulan}

Dari data-data di atas kita lihat bahwa terdapat perbedaan-perbedaan antara dengan dan tanpa menggunakan alat kompresor udara tersebut. Dengan kata lain menggunakan alat kompresor udara ini terjadi sedikit penyimpangan dari keadaan standarnya. Namun demikian alat kompresor udara ini apabila digunakan tidak akan merusak kendaraan atau menguangi performa mesin sepeda motor. Karena alat ini digunakan pada saat sepeda motor kita berhenti atau mesin sepeda motor kita tidak dalam keadaan bergerak..

\section{Saran}

Alat ini dikhususkan untuk dapat digunakan pada sepeda motor 4 langkah, karena sepeda motor 4 langkah menggunakan sistem pelumasan yang berstandar sirkulasi minyak pelumas atau oli, sehingga pada aplikasi alat kompresor ini tidak menimbulkan resiko kerusakan atau keausan tingkat berat atau berbahaya pada komponen pembangkit daya motor bakar.

\section{DAFTAR PUSTAKA}

Fritz Dietzel. 1988. Turbin Pompa dan Kompresor. Erlangga. Jakarta.

Robingu Usman. Drs. Sardjijo. Drs.1979. Motor

Bakar. Dikmenjur. Jakarta.

Sularso. Ir. MsME. 1980. Dasar Perencanaan dan

Pemilihan Elemen Mesin. PT Pradnya

Paramita.Jakarta.

Sularso. Ir. MsME. 1983. Pompa dan Kompresor. PT pradnya Paramita.Jakarta.

Suzuki (Indomobil). 2004. Pedoman Perwatan. Indo Mobil. Jakarta

Sugihartono. Drs. 1985. Dasar-dasar Kontrol

Penematik. Tarsito.Bandung.

Sugihartono. Drs. 1988. Sistem Kontrol dan Pesawat Tenaga Hidrolik. Tarsito. Bandung.

http: //ekshter. Blogspot.Com/2008/12/kompresorudara-part-ii.html.

Wiranto Arismunandar. 1983. Penggerak Mula Motor Bakar Torak. Bandung ITB. 